\title{
MARKETING STRATEGY FOR LOCAL SUPERIOR COMMODITIES AND REGIONAL ECONOMIC CONTRIBUTIONS OF INDONESIA
}

\author{
Senny Luckyardi \\ Department of Management, Universitas Komputer Indonesia, Bandung, Indonesia \\ Eddy Soeryanto Soegoto \\ Department of Management, Universitas Komputer Indonesia, Bandung, Indonesia
}

Sri Supatmi

Department of Electrical Engineering, Universitas Komputer Indonesia, Bandung, Indonesia

\section{Lia Warlina}

Department of Urban and Regional Planning, Universitas Komputer Indonesia, Bandung, Indonesia

Faridah Hj Hassan

AAGBS Universiti Teknologi MARA, Shah Alam, Malaysia

\begin{abstract}
To boost the development of a regional agricultural sector, a wider scope of superior commodities can be used. It certainly would contribute a lot to regional and national economic sustainability. Therefore, the stakeholders need to formulate an effective and efficient marketing strategy to balance the supply and demand of agricultural products and improve farmers' welfare. Marketing strategies in each country were differently influenced by several factors ranging from geography, politics, and people's consumption patterns. This study compares the marketing strategies for leading agricultural commodities in Indonesia and Uzbekistan to obtain a new formula for marketing agricultural products. Uzbekistan is considered one of the countries in Central Asia that has a lot in common with Indonesia, especially in the agricultural sector, and vice versa. This study aims to develop a marketing strategy for enhanced regional commodities and see how significant the economic contribution of the Garut region is on a national scale. The Literature review is used as a research method. We also conducted a case study and field survey in the Garut region, one of the agriculture centers in Indonesia. The results also indicate that a marketing strategy can boost the economy of a specific area. It can be useful for local governments and business entities when developing effective strategies to deal with the national economy and for monitoring of farmer effectiveness.
\end{abstract}

Keywords: Agricultural, Commodities, Marketing, Strategy, Sustainability

DOI: http://dx.doi.org/10.15549/jeecar.v9i1.866 


\section{INTRODUCTION}

One of the elements in regional economic development is economic growth. It is because economic growth in an area will affect the level of welfare of its people. One sector that contributes to economic development in Indonesia is agriculture (Kotler et al., 2013; Widianingsih, 2013). The agricultural sector in Indonesia, such as seasonal vegetables and fruit commodities, contributes to horticultural production and inflation. One of the leading commodities in Indonesia is shallots. It can be seen from the total shallot production in 2020 reaching 1.82 million tons (an increase of $14.88 \%$ from 2019), with the total consumption by the household sector in 2021 amounting to $729.082,000$ tons. The highest production of shallots occurred in December of 203.02 thousand tons with a harvested area of 21.37 thousand hectares (Assauri Sofjan, 2017; Statistik, 2020).

Judging from the distribution of shallot production in supporting the GRDP in Indonesia, the province of West Java has a contribution of $7.7 \%$ of the $18 \%$ of the National GRDP. It is supported by data from the Central Statistics Agency of West Java Province, which notes that the Regency area contributes more to GRDP, which is $23.53 \%$ compared to the city area of 3.7\%. Provincial GRDP supports the production of shallots in West Java Province, one of which is Garut Regency. At the provincial level, the production of shallots in Garut Regency is 321 tons out of 1.7 million tons of total production in West Java and supports $18 \%$ of the Province's GRDP. The amount of this contribution impacts the availability of jobs in Garut Regency, which farmers still dominate.

Therefore, in improving the welfare of farmers in the Garut Regency, it is necessary to have the right strategy by considering the concept of a green economy. Therefore, two things need to be considered to expand the market share of shallot sales in Garut Regency through the right marketing strategy. A marketing strategy is a plan in describing the company's expectations by identifying the impact of marketing activities or programs on product demand in certain target markets (Kotler et al., 2013). Therefore, in preparing a marketing strategy, an integrated and comprehensive plan is needed in marketing that guides the activities to be carried out to achieve a company's marketing objectives (Assauri Sofjan, 2017).

Several previous studies on marketing studies for superior local commodities have been conducted. Syahza et al. (2020) discussed the prospects for accelerating rural economic development through the development of leading commodities in coastal areas, as well as the potential of superior commodities in terms of farm efficiency and opportunities to create added value for farmers. Sulistyowarni et al. (2020) conducted another study to examine the potential of the banana commodity, which can be used optimally by employing defense economics, food security theory, and demand-supply. The findings indicate that bananas as a commodity have a high potential for development in the Bogor District. Gunawan et al. (2028) discussed the analysis of the determination of superior local commodities using the location quotient technique, as well as the contribution of superior products to the regional economy. The results show that tobacco commodities contribute positively to the regional economy. Furthermore, the Central Asian country, Uzbekistan, has a full focus on the agricultural sector, especially when the COVID-19 pandemic comes. It can be seen from the policies carried out by the government directly to make a long-term strategy for the years 2020-2030. The policy prioritizes the development and implementation of state policies on food security utilizing large-scale procurement of agricultural production materials such as seeds and technology. From October 2020, an intervention procurement system will be introduced gradually to provide the population with an uninterrupted supply of grain products and prevent sharp price fluctuations (Dadabaev, U. A. U. et al., 2021).

From these several studies, there has been no discussion of marketing strategies for local, superior commodities to support the national economy. Therefore, this study will discuss marketing strategies to maximize the potential of local commodities to improve the national economy.

Meanwhile, the first step before formulating a marketing strategy is to conduct a Location Quotient (LQ) analysis. LQ analysis measures the performance of a region's economic base and the concentration of a leading region on the regional and national economy. Therefore, the purpose of this study is to analyze the LQ of the shallot 
commodity, as well as the distribution of the shallot commodity in Garut Regency, to assist the government in formulating a marketing strategy by considering the green economy concept.

\section{LITERATURE REVIEW}

Regional Economy in Indonesia and Uzbekistan Indonesia has officially implemented a fiscal decentralization policy by shifting the responsibility for spending and/or income that is more dominant to lower government units. The main factor in determining this decentralization is how the government with the lowest unit can allocate spending, especially in the economic sector (Lamba et al., 2019). The decentralization policy is expected to increase economic growth to provide freedom of transaction and maximize existing resources. Economic growth measures the achievement of the development of an economy in an area or a group boundary. Measuring an economy's progress necessitates the use of appropriate measuring tools, such as Gross Domestic Product (GDP). Sendouw (2014) explains that GDP is a metric that measures the number of services and goods produced by an economy in a given year and is expressed in market prices. Indonesia plays an important role in improving the economy's use of renewable energy sources, such as fossil fuels, which account for approximately 96 percent of total primary energy consumption (NEC, 2015). Many efforts have been made to disseminate Indonesia's rich diversity of renewable resources. These efforts include the development of energy policies and regulations but still have not yielded satisfactory results on Indonesia's global economic growth (Hasan et al., 2012).

Agriculture is the only sector that recorded growth in Indonesia's Total Factor Productivity (TFP), which is positive. This increase in productivity accounts for 30 percent of the actual value-added growth in agriculture and 3.5 percent of the overall economic growth. The agricultural sector in Indonesia is a reference in economic growth. When agriculture increases, it is part of the economic improvement in ASEAN countries, especially Indonesia (Gunawan et al,2018). Furthermore, agriculture is important in Uzbekistan for employment, rural income, national food security, and livelihood. Hasanov (2016) said that agriculture, traditionally divided into various regions, contributes strongly and is relatively stable to the economy of Uzbekistan
(Hasanov, 2016). The agricultural sector grew at a 7\% annual rate between 2000 and 2013. Despite this growth rate, the sector's share of GDP fell from 32 to 17.6 percent between 1995 and 2015 as other industries grew faster. Crop production accounts for roughly 60\% of total agricultural value, with livestock also playing a role.

\section{Leading Local Commodities in Indonesia and Uzbekistan}

Leading commodities are physical products from agriculture that can support the economic and social conditions of the community to be developed better and in large quantities in an area. The agricultural sector in Indonesia is very dominant, with large results in supporting domestic needs (Gunawan et al., 2018). One of them is in Garut Regency, West Java, with superior commodities such as red chilies, oranges, and corn. These three commodities are well known and have been widely distributed to many regions in Indonesia and support national needs (Djuwendah et al., 2013). Cotton is the most important crop in Uzbekistan, where the country ranks fifth out of 90 cotton-producing countries, accounting for 6\% of global cotton production (Djanibekov, 2010; Shavkatovna, D. G. 2019). Aside from cotton, wheat is Uzbekistan's second-largest superior commodity. Cotton and wheat are grown separately in 75.6 percent of the country, with the remaining land planted with vegetables and fruits, tobacco, fodder crops and potatoes. Uzbekistan remains a major supplier of fresh and processed vegetables and fruits (Sultanov, B. et al., 2021; Kholmamatovich, K. U. 2020).

\section{Marketing Strategy in Agricultural Sector in Indonesia and Uzbekistan}

Uzbekistan's agriculture strategy ensures a consistent supply of fruits and vegetables. To accomplish this, a long-term approach to processing and distribution is required rather than focusing on increasing output in the short term. Particularly important for the smooth implementation of agricultural product processing clusters is strengthening a stable production system in tandem with increased farmer capacity (Khidirov et al., 2015).). Increased value-added in sub-sectors and market access can be attained through interventions such as encouraging the identification of potential markets, commercialization of 
production, ensuring quality standards, encouraging private sector participation in agricultural product processing, promoting comarketing and distribution channels, and adopting new varieties and production technologies. Djanibekov and Finger, 2018; A. Bobokhonov et al., 2017; Khakimov and Toxirovna, 2020). Hasanov (2016) explains how efficient processing methods can be for exporting high-quality processed foods. The implementation of marketing strategies for MSMEs in Indonesia includes improving the quality of excellent service, maintaining the existence of the business environment and business relations, developing product delivery in collaboration with the government and private parties, maximizing promotional activities by increasing market networks both from the agricultural service and independently with the internet, adjusting product prices with raw material costs, creating product innovations in terms of perception and form, adjusting product prices to customer willingness to pay, and establishing permanent outlets as centers of superior commodities (Yulia et al,2019; Ramli, Y., \& Soelton, M. 2018). This marketing strategy is in line with the main concept of the green economy in Indonesia, which focuses on alleviating poverty and minimizing the cost of environmental care (Martawardaya et al. 2021). The green economy in Indonesia has special characteristics according to environmental conditions and is not limited to emphasizing the use of natural resources effectively and efficiently (DeLacy, T., \& Jiang, M. 2019). Therefore, with abundant natural resources, the community can use them as much as possible while maintaining environmental sustainability (Iskandar et al, 2019).

\section{METHOD}

This study used several methods, namely the method of analysis and calculation. The Location Quotient (LQ) is a method of determining the degree of specialization of economic sectors in an area that uses the base sector or leading sector. The location quotient compares the output share of the sector I in the city or district to the output share of the sector I in the province. The leading sector refers to the business sector that will not be depleted if the regional government capitalizes on it. The location quotient is a simpler economic development tool with all of its benefits and drawbacks (Niyimbanira et al., 2020). The study used an analysis of the economic basis theory where an assessment is made of the economic growth rate of the increase in exports from that region through the magnitude. The data used are secondary data from the Garut Regency Agriculture Service and the Central Statistics Agency. The research location is in Garut Regency because the shallot commodity in Garut Regency can support 16-17\% of provincial needs and 7-8\% of national demand.

$$
\mathrm{LQ}=\frac{V i / V t}{Y i / Y t}
$$

$\mathrm{Vi}=\mathrm{PDRB}$ value of sector $\mathrm{i}$ at a lower regional level

$\mathrm{Vt}=$ total PDRB at the lower regional level

$\mathrm{Yi}=$ PDRB value of sector $\mathrm{i}$ at the higher regional level

Yt $=$ Total PDRB at the higher regional level

\section{RESULTS AND DISCUSSION}

The LQ value calculates a sector's ability to contribute to regional economic growth. The calculation of LQ can be done based on the labor approach and the value-added approach or regional gross domestic product (GRDP) in the sector. In this study, the LQ calculation uses a GRDP approach focusing on the agriculture sector. Based on Garut Regency GRDP data, it was known that the agriculture sector in 2020 produces 22,038.91 billion rupiahs with a total GRDP in 2020 of $58,043.00$ billion rupiahs. In West Java province in 2020, the GRDP of the agriculture sector was 192,117.06 billion rupiahs, with a total GRDP of 2,088,038.74 billion rupiahs. The following is an analysis of the calculation of the LQ value from the agriculture sector in Garut Regency:

$$
\begin{aligned}
& \mathrm{LQ}=\frac{V i / V t}{Y i / Y t} \\
& \mathrm{LQ}=\frac{\left(\frac{22.038,91}{58.043,00}\right)}{\left(\frac{192.117,06}{2.088 .038,74}\right)} \\
& \mathrm{LQ}=4,119(4)
\end{aligned}
$$

$\mathrm{Vi}=$ PDRB value of sector $\mathrm{i}$ at lower regional level

$\mathrm{Vt}=$ total PDRB at the lower regional level

$\mathrm{Yi}=$ PDRB value of sector $\mathrm{i}$ at the higher regional level

$Y t=$ Total PDRB at the higher regional level 
The analysis results obtained an LQ value of 4 (LQ> 1), which indicates that the agriculture sector is the base sector in West Java Province, especially in the Garut Regency. Agricultural commodities can be defined as a sector that supports economic growth, potentially competing with other regions (exports). One of the leading commodities in the agriculture sector in Garut Regency is shallots. The area with the largest shallot production in Garut Regency is in Bayongbong District (154,346 quintals in 2020). The shallot farming area in Bayongbong District is $1,521 \mathrm{ha}$ ).

Rea of shallot farming in Garut Regency from 2019 to 2020 decreased by an average of $0.17 \%$ (see Table 1). It is due to the conditions during the pandemic affecting all economic factors, especially in business capital for agriculture. Even so, during the pandemic, the agriculture sector could still survive compared to other sectors such as trade, services, and tourism which experienced a significant decline. It is shown from the percentage decline in the workforce in Indonesia based on the agriculture sector. It is known that West Java Province only experienced a decrease in the workforce by $0.08 \%$.

In table 1 , it is known that the largest production is in the Bayongbong sub-district, wherein 2019-2020, the resulting production reaches a total of 308,692 quintals with a total harvested area of 3,688 (Ha). 'In addition, it is shown that the smallest production is found in the Bungbulang sub-district, where in the 20192020 period, the Bungbulang sub-district can only produce a total of 204 quintals where this is due to the harvest area, which only reaches 1 ha.

Based on the data displayed, the average production and land in Garut Regency, where in the 2019-2020 period from 42 registered subdistricts, the average production can be 3,126 quintals and the average available harvested land are $3.084(\mathrm{Ha})$.

Table 1: Distribution of Shallots in Garut Regency in 2019-2020

\begin{tabular}{|c|c|c|c|c|c|}
\hline \multirow{2}{*}{ No } & \multirow{2}{*}{ Districts } & \multicolumn{2}{|c|}{ Harvest Area (Ha) } & \multicolumn{2}{|c|}{ Production (quintal) } \\
\hline & & 2019 & 2020 & 2019 & 2020 \\
\hline 1 & Cisewu & - & - & - & - \\
\hline 2 & Caringin & - & - & - & - \\
\hline 3 & Talegong & - & - & - & - \\
\hline 4 & Bungbulang & - & 1 & 102 & 102 \\
\hline 5 & Mekarmukti & - & - & - & - \\
\hline 6 & Pakenjeng & 10 & 17 & - & - \\
\hline 7 & Pamulihan & - & - & 1675 & 1675 \\
\hline 8 & Pameungpeuk & - & - & - & - \\
\hline 9 & Cikelet & - & - & - & - \\
\hline 10 & Cisompet & - & - & - & - \\
\hline 11 & Cibalong & - & - & - & - \\
\hline 12 & Cihurip & - & 3 & - & - \\
\hline 13 & Singajaya & - & - & - & - \\
\hline 14 & Cikajang & 15 & 13 & 1298 & 1298 \\
\hline 15 & Peundeuy & - & - & 298 & 298 \\
\hline 16 & Banjarwangi & - & - & - & - \\
\hline 17 & Cilawu & 135 & 222 & 17095 & 17095 \\
\hline 18 & Bayongbong & 2.103 & 1.585 & 154346 & 154346 \\
\hline 19 & Cigedug & 43 & 49 & 4791 & 4791 \\
\hline 20 & Cisurupan & 121 & 210 & 20432 & 20432 \\
\hline 21 & Sukaresmi & 203 & 96 & 9846 & 9846 \\
\hline 22 & Samarang & 101 & 124 & 12082 & 12082 \\
\hline
\end{tabular}


Table 1: Continued

\begin{tabular}{|c|c|c|c|c|c|}
\hline \multirow{2}{*}{ No } & \multirow{2}{*}{ Districts } & \multicolumn{2}{|c|}{ Harvest Area (Ha) } & \multicolumn{2}{|c|}{ Production (quintal) } \\
\hline & & 2019 & 2020 & 2019 & 2020 \\
\hline 23 & Pasirwangi & 13 & 55 & 5373 & 5373 \\
\hline 24 & Tarogong Kaler & 11 & 2 & 126 & 126 \\
\hline 25 & Tarogong Kidul & 10 & 1 & 198 & 198 \\
\hline 26 & Garut Kota & 43 & 17 & 1516 & 1516 \\
\hline 27 & Karangpawitan & 20 & 28 & 2720 & 2720 \\
\hline 28 & Wanaraja & 48 & 47 & 4681 & 4681 \\
\hline 29 & Pangatikan & 152 & 59 & 24277 & 24277 \\
\hline 30 & Sucinaraja & 208 & 249 & 5350 & 5350 \\
\hline 31 & Sukawening & 10 & 13 & 1329 & 1329 \\
\hline 32 & Kr. Tengah & 22 & 18 & 1773 & 1773 \\
\hline 33 & Banyuresmi & - & - & - & - \\
\hline 34 & Leles & 11 & 15 & 1466 & 1466 \\
\hline 35 & Leuwigoong & - & - & - & - \\
\hline 36 & Kadungora & - & - & - & - \\
\hline 37 & Cibiuk & 12 & 4 & - & - \\
\hline 38 & Cibatu & - & - & 390 & 390 \\
\hline 39 & Kersamanah & - & - & - & - \\
\hline 40 & Malangbong & 8 & 6 & 1472 & 1472 \\
\hline 41 & Limbangan & 18 & 15 & 103 & 103 \\
\hline 42 & Selaawi & - & 1 & 607 & 607 \\
\hline & Total & 3.317 & 2.850 & 4428 & 1824 \\
\hline
\end{tabular}

Table 1 explains the distribution of agricultural production in Garut Regency, which is grouped by sub-district. To see in detail, the data is presented on a map to provide a clearer visualization based on its geographic value to determine the distribution of agriculture and its potential (Figure 1). Figure 1 is divided into five color groups. The darker the color, the higher the amount of agricultural production. The five groups are $<2,500$ quintals, 2,500 - 5,000 quintals, 5,001 - 7,500 quintals, 7,501 - 10,000 quintals, and $>10,000$ quintals. The map shows that Garut Regency is a center for agriculture, especially shallots, since it is very dominant in the area with a solid red color, which means lots of agricultural produce. With these dominant results, Garut Regency is one of Indonesia's pillars of national agrarian products (Gunawan et al., 2018).

Meanwhile, Uzbekistan has agro-climatic conditions suitable for producing various vegetable and fruit crops, well known in Central Asia (CA) and abroad. Uzbekistan's agricultural, horticultural, and vegetable sectors are growing very fast. Cotton-wheat crop rotation is a common practice. More than 6 million tons of wheat and 3 million tons of raw cotton are produced every year. While cotton has been Uzbekistan's main agricultural crop for over a century, the country is also a major producer of vegetables and a supplier to the rest of the former Soviet Union [FSU] (Karimov, 2013). Uzbekistan is primarily a cotton-producing economy, with cotton accounting for 60 per cent of agricultural output and 30 per cent of export income (Lombardozzi, L. 2019). 


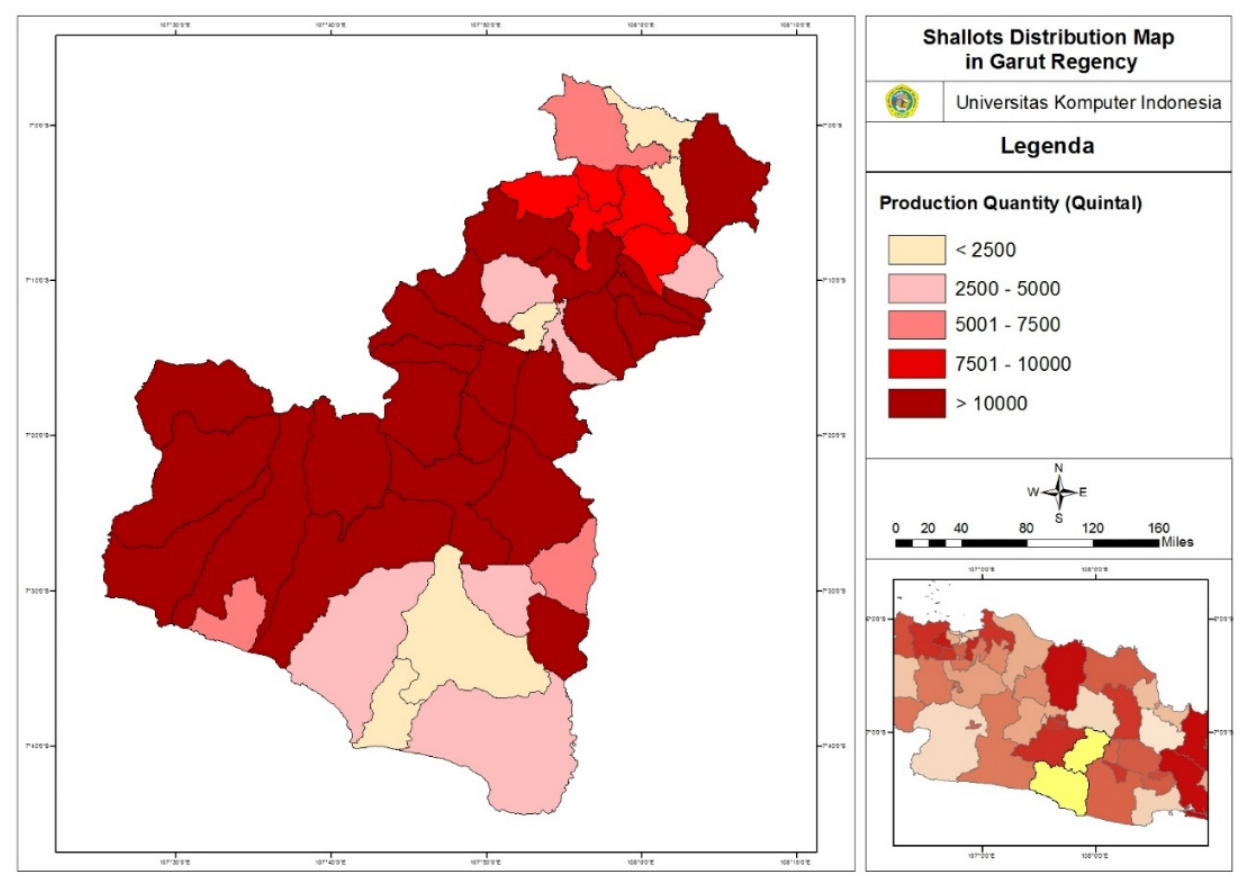

Figure 1: Map of Distribution of Shallot Agricultural Products in Garut Regency Source: Agricultural Office of Garut Regency, 2020

Cotton production also means future linkages regarding gin manufacturing and textile production in the economy. According to the State Statistics Committee of the Republic of Uzbekistan, in comparison with JanuaryDecember 2019, Uzbekistan's GDP in 2020 increased by $1.6 \%$ (Nurbekov, A. et al. 2018). It is one of the best indicators among European and Central Asian countries during the crisis of the coronavirus pandemic.

\section{CONCLUSION}

The business of agriculture crops has a large opportunity to become a superior product that plays an important role in improving the regional economy. Therefore, the marketing strategy aims to realize productive, efficient, and competitive agriculture. To achieve sustainable quality production, institutional support must be oriented towards local markets and export markets. Support from the government is also needed in the form of policies related to planning for the use of local labor and human resource development, especially in superior commodity plantations that bring positive changes and impact state revenues. Therefore, efforts are needed to utilize resources to support sociocultural and environmental resilience optimally. Based on the analysis of research results and discussions, a commodity development strategy is obtained for each sub-district. In addition, it is necessary to develop superior commodities in the base regions, so that competitiveness in the region increases and the need for commodity development activities in non-base regions so that production can be further increased.

\section{REFERENCES}

Assauri Sofjan. (2017). Manajemen Pemasaran Dasar dan Konsep Strategi. Jakarta: PT Rajawali Pres.

Bobokhonov, A., Pokrivcak, J., \& Rajcaniova, M. (2017). The impact of agricultural and trade policies on price transmission: The case of Tajikistan and Uzbekistan. The Journal of International Trade \& Economic Development, 26(6), 677-692.

Dadabaev, U. A. U., Isadjanov, A. A., Sodikov, Z. R., Mukhitdinov, S. Z., \& Batirova, N. S. (2021). Ways to increase the export potential of agricultural products of Uzbekistan in a pandemic. International Journal of Modern Agriculture, 10(2), 24662479.

DeLacy, T., \& Jiang, M. (2019, November). Transforming a tourism destination into a green economy: A policy analysis of 
Wakatobi Islands, Indonesia. In IOP Conference Series: Earth and Environmental Science, 363(1), 012004. IOP Publishing.

Djanibekov, N., Rudenko, I., Lamers, J., \& Bobojonov, I. (2010). Pros and cons of cotton production in Uzbekistan.

Djanibekov, U., \& Finger, R. (2018). Agricultural risks and farm land consolidation process in transition countries: the case of cotton production in Uzbekistan. Agricultural systems, 164, 223-235.

Djuwendah, E., Hapsari, H., Renaldy, E., \& Saidah, Z. (2013). Strategi pengembangan daerah tertinggal di Kabupaten Garut. Sosiohumaniora, 15(2), 167-177.

Gunawan, G., Cahyono, A. E., \& Santoso, A. (2018). Local superior commodities, regional specialisations and regional economic contributions. The Journal of Distribution Science, 16(9), 35-41.

Gunawan, G., Cahyono, A. E., \& Santoso, A. (2018). Local superior commodities, regional specializations and regional economic contributions. The Journal of Distribution Science, 16(9), 35-41.

Hasan, M.H., Mahlia, T.M.I. and Nur, Hadi. (2012). A review on energy scenario and sustainable energy in Indonesia. Renewable and Sustainable Energy Reviews, 16(4), pp.2316-2328

Hasanov, S. (2016). Agricultural polices to enhance the development of fruit and vegetable subsectors in Uzbekistan. European Scientific Journal, 12(13), 479491.

Iskandar, A., \& Aqbar, K. (2019). Green Economy Indonesia Dalam Perspektif Maqashid Syari'ah. Al-Mashrafiyah: Jurnal Ekonomi, Keuangan, dan Perbankan Syariah, 3(2), 8394.

Karimov, A. (2013). Economic inefficiency and shadow prices of inputs: the case of vegetable growing farms in Uzbekistan. Procedia Economics and Finance, 5, 403412.

Khakimov, R., \& Toxirovna, S. G. (2020). Agrarian Sector of the Republic of Uzbekistan in a Way of Development and Features of Enterprise Activity. International Journal on Orange Technologies, 2(10), 53-57.
Khidirov, D., Larson, D. F., \& Schuman, I. (2015). Uzbekistan-Strengthening the horticulture value chain (No. 94281, pp. 1-102). The World Bank.

Kholmamatovich, K. U., Choriyevich, N. I., \& Nasimovna, B. S. (2020). Results of Varietal Testing of Peking Cabbage with a Repeated Planting in Uzbekistan. International Journal on Orange Technologies, 2(10), 20-23.

Kotler, P., Armstrong, G., Harris, L. C., \& Piercy, N. (2013). Principles of Marketing. 6th

European edition. Essex: Pearson Education Limited.

Lamba, A., Allo, P. K., \& Lamba, R. A. (2019). Effect of fiscal decentralisation policy of regional economic imbalances towards economy growth in Eastern Indonesia. International Journal of Social Sciences and Humanities, 3(2), 112-127.

Lombardozzi, L. (2019). Can distortions in agriculture support structural transformation? The case of Uzbekistan. Post-Communist Economies, 31(1), 52-74.

Martawardaya, B., Rakatama, A., Junifta, D. Y., \& Maharani, D. A. (2021). Green economy post COVID-19: insights from Indonesia. Development in Practice, 1-9.

NEC. (2015). Executive Reference Data National Energy Management. National Energy Council, Jakarta

Niyimbanira, F., Eggink, M. E., \& NishimweNiyimbanira, R. (2020). The identification of the key sub-industries among coastal metropolitan cities of South Africa: An application of the location quotient technique. International Journal of Economics and Finance Studies, 12(1), 5070.

Nurbekov, A., Aksoy, U., Muminjanov, H., Khujabekov, A., Nurbekova, R., \& Shukurov, A. (2018, August). Organic agriculture in Uzbekistan. In $X X X$ International Horticultural Congress IHC2018: II International Symposium on Organic Horticulture for Wellbeing of the 1286 (pp. 11-16).

Ramli, Y., \& Soelton, M. (2018). Implementing innovation management on market attractiveness and unique resources to enhance business performance on organic fertilizer industries in Indonesia. Academy 
of Strategic Management Journal, 17(2), 112.

Sendouw, R. (2014). the economic growth and the regional characteristics: the case of indonesia. Buletin Ekonomi Moneter dan Perbankan, 16(1), 3-18.

Shavkatovna, D. G. (2019). Aspects of Agricultural Market Development in Uzbekistan. Asian Journal of Technology \& Management Research (AJTMR) ISSN, 2249(0892).

Statistik, B. P. (2020). STATISTIK HORTIKULTURA 2020. Horticultural Statistics, 2020

Statistik, B. P. (2021). Produk Domestik Bruto Indonesia Triwulanan. BPS-Statistics Indonesia, Jakarta.

Sulistyowarni, I., Sundari, S., \& Halim, S. (2020). THE POTENTIAL OF BANANA TRADING COMMODITY TO FULFILL MARKET DEMAND AND SUPPORT FOOD SECURITY IN DEFENSE ECONOMIC PERSPECTIVE (STUDY IN BOGOR DISTRICT). Jurnal Pertahanan \& Bela Negara, 10(3), 307-332

Sultanov, B., Amirov, L., Askarova, M., Rakhmankulova, B., \& Tosheva, M. (2021). Agriculture of the Republic of Uzbekistan after the peak of the pandemic. In E3S Web of Conferences (Vol. 244, p. 03024). EDP Sciences.

Sultonov, M., Sh, I., \& Rustamov, A. (2018). Usage Biogas Plants with regarding climate conditions of Uzbekistan. International Journal of Advanced research in science, Engineering and technology-IJARSET, 5(1), 3619-3622.

Syahza, A., Bakce, D., Irianti, M., Asmit, B., ASMIT, B., SYAHZA, A., \& Hasbi, M. (2020). Potential Development of Leading Commodities in Efforts to Accelerate Rural Economic Development in Coastal Areas Riau, Indonesia. Journal of Applied Sciences, 20(5), 173-181.

Widianingsih, W., Suryantini, A., \& Irham, I. (2015). Kontribusi Sektor Pertanian Pada Pertumbuhan Ekonomi Di Provinsi Jawa Barat. Agro Ekonomi, 26(2), 206-218.

Yulia, Y., Bahtera, N. I., \& Evahelda, E. (2019). A SWOT Analysis on the Implementation of the Marketing Strategy: A Case Study in the Raja Abon Makmur Lestari, Pangkalpinang City, Indonesia. International Journal of Business and Economy, 1(2), 24-30.

\section{ABOUT THE AUTHORS}

Senny Luckyardi, email: senny@email.unikom.ac.id

Senny Luckyardi, Management Department, Faculty of Economic and Business, Universitas Komputer Indonesia, Bandung, Indonesia.

Eddy Soeryanto Soegoto, Management Department, Faculty of Economic and Business, Universitas Komputer Indonesia, Bandung, Indonesia.

Lia Warlina, Urban and Regional Planning Department, Faculty of Engineering and Computer Science, Universitas Komputer Indonesia, Bandung, Indonesia.

Sri Supatmi, Electrical Engineering Department, Faculty of Engineering and Computer Science, Universitas Komputer Indonesia, Bandung, Indonesia.

Faridah HJ Hassan, Faculty of AAGBS Universiti Teknologi MARA, Shah Alam, Malaysia. 